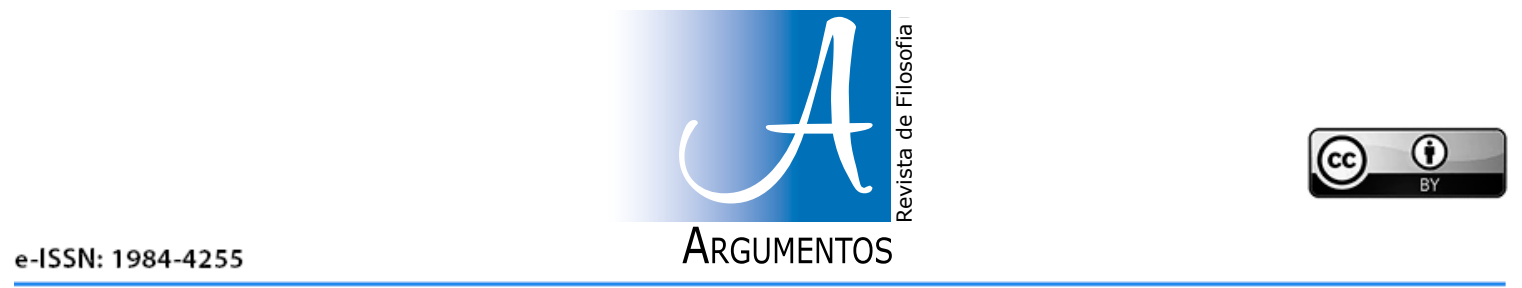

D0I: https://doi.org/10.36517/Argumentos.24.4

\title{
Diógenes Laércio e a ética estoica
}

\section{Diogenes Laertius and the stoic ethics}

\author{
José Carlos Silva de Almeida \\ Orcid: https://orcid.org/0000-0002-9017-8755 - E-mail:jcdafilosofia@hotmail.com
}

\section{RESUMO}

Este artigo apresenta conceitos importantes da ética estoica e suas conexões encontrados na versão de Diógenes Laércio no livro VII do Vidas e doutrinas dos filósofos ilustres. Diferentemente de Cícero no livro III do De finibus, a formulação de Diógenes não é assinalada por habilidades retóricas e acaba por seguir o tecnicismo presente também no livro II das Éclogas de Ário Dídimo. Diógenes, sem se preocupar em dar uma feição mais de divulgação às exposições dos estoicos, não dissimula as dificuldades e as frequentes excentricidades da filosofia estoica, que por vezes apresenta raciocínios pouco sedutores e até mesmo tediosos.

Palavras-chave: Ética. Estoicismo. Diógenes Laércio.

\begin{abstract}
This article presents important concepts of Stoic ethics and their connections found in the version of Diogenes Laetius in book VII of Lives and doctrines of the eminent philosophers. Unlike Cicero in book III of De finibus, Diogenes' formulation is not marked by rhetorical skills and ends up following the technicality present in book II of Eclogues by Arius Didymus. Diogenes, without worrying about giving a more public appearance to Stoic exhibitions, does not hide the difficulties and frequent eccentricities of Stoic philosophy, which sometimes presents unattractive and even tedious reasoning.
\end{abstract}

Keywords: Ethics. Stoicism. Diogenes Laertius. 
Assim como ocorre com os pré-socráticos, também os estoicos são estudados a partir de fragmentos, ou seja, citações das suas doutrinas feitas por outros autores. Estes fragmentos foram reunidos no início do século XX por Hans von Arnim ${ }^{1}$, em uma coleção denominada Stoicorum veterum fragmenta, ainda hoje em uso e criticada por muitos, porque mescla testemunhos de épocas diferentes sobre argumentos singulares, tornando assim difícil uma reconstrução clara da doutrina.

Já no século passado, esta literatura, que os modernos denominam "doxográfica" seja, com o fim de reunir e de confrontar as mais variadas opiniões filosóficas sobre o mesmo argumento, foi estudada de maneira aprofundada e obteve resultados significativos. Neste sentido podemos destacar, na Itália, a Storiografia e dossografia nella filosofia antica, trabalho organizado por Giuseppe Cambiano ${ }^{3}$, além dos dois números monográficos dedicados pela revista Elenchos ${ }^{4}$ ao método historiográfico de Diógenes Laércio ${ }^{5}$ e o amplo estudo I dossografi di etica, especialmente dedicado à coleção de opiniões no campo ético de Michelangelo Giusta 6 . Embora os estudiosos discordem sobre certos aspectos, algumas características típicas do gênero literário doxográfico parecem já esclarecidas, e portanto é possível tecer afirmações razoavelmente seguras sobre o panorama da ética estoica.

Parece não haver dúvida de que Diógenes Laércio (século III d.C.) não compilou diretamente e de uma única fonte o panorama que apresenta acerca da ética estoica, mas o retomou de uma literatura mais antiga. Em geral, considera-se que a doxografia da ética estoica de Diógenes remonte ao I século a.C., e que retome a visão do pensamento estoico que se tinha na época do imperador Augusto. Todavia há quem postule que em tal apresentação se encontrem traços do pensamento dos estoicos mais antigos, especialmente o de Crisipo.

Em geral, pode-se afirmar que o tom da doxografia de Diógenes não é crítico e nem excessivamente elogiativo. Ele não procura refutar ou tecer um panegírico do pensamento estoico, mas apresentá-lo com um tom destacado e de forma imparcial:

Pareceu-nos oportuno apresentar nesta Vida de Zênon um resumo abrangente de todo o conjunto da doutrina estoica, pelo fato de ter sido Zênon o fundador da escola estoica. Já demos a lista de seus muitos escritos, nos quais manifestou-se como nenhum dos outros estoicos. Expomos a seguir as doutrinas fundamentais em seus elementos essenciais e gerais. De acordo com o nosso método habitual, é suficiente uma exposição sumária. (D.L. VII, 38, p. 190).?

\footnotetext{
1 A edição de referência dos fragmentos dos estoicos é Hans von Arnim, Stoicorum veterum fragmenta, 4 vols., Leipzig, 1903-1923. Para as traduções em italiano veja-se Nicola Festa, I frammenti degli Stoici antichi, 2 vols., Laterza, Bari, 1932-1953; Rosario Anastasi, I frammenti degli Stoici antichi, CEDAM, Pádua, 1962; Margherita Isnardi Parente, Stoici antichi, 2 vols., UTET, Turim, 1989. Uma edição mais recente dos fragmentos dos estoicos antigos, conforme a coleção de Hans von Arnim é aquela organizada por Roberto Radice e apresentada na coleção Il pensiero occidentale da editora Bompiani (2002). Atualmente a melhor coleção dos fragmentos dos filósofos helenísticos com texto crítico e comentário é The Hellenistic Philosophers de A. A. Long e D. N. Sedley em dois volumes, publicada, em 1987, pela Cambridge University Press.

2 O termo "doxografia" e aqueles a esse relacionados não se encontram na língua grega antiga, mas foram criados pela filologia oitocentista. Por muito tempo teve um certo significado negativo, visto que indicava a obra de quem recolhe notícias sobre as opiniões dos filósofos sem ter a sua própria perspectiva teorética. A este modo de proceder aparecia em oposição a "historiografia filosófica" mais aprofundada de Aristóteles ou de Hegel. Hoje, o termo "doxografia" é utilizado de maneira puramente descritiva.

${ }^{3}$ Publicado pela editora Tirrenia de Turim em 1986.

${ }^{4}$ Revista de estudos sobre o pensamento antigo, publicada pela editora Bibliopolis de Nápoles.

5 № 7, 1986, fascículos 1 e 2.

6 Publicado pela editora G. Giappichelli de Turim, entre 1964 e 1967.

7 Utilizamos, para as citações do Vidas e doutrinas dos filósofos ilustres de Diógenes Laércio, a tradução de Mário da Gama Kury, publicada pela editora da UNB em 1977. As citações são apresentadas indicando as iniciais do autor, o livro, o parágrafo e o número da(s) página(s).
} 
Diógenes inicia a exposição da doutrina estoica apresentando a divisão tripartite da filosofia em lógica, física e ética ${ }^{8}$, conforme postula a escola. A lógica antiga continha, além da lógica, a filosofia da linguagem e a epistemologia, enquanto a física antiga compreendia a metafísica e a teologia. Cada parte da filosofia podia ser estudada por si mesma, ou também considerando as suas relações com as demais partes. Nenhuma das partes tem o papel de fundamento, visto que todas as três são caracterizadas pela interdependência recíproca, dando lugar a um sistema holístico. As metáforas que os estoicos lançam mão para tratar da filosofia nos oferecem uma boa ideia a respeito dessa interdependência recíproca das partes:

Os estoicos comparam a filosofia a um ser vivo, onde os ossos e os nervos correspondem à lógica, as partes carnosas à ética e a alma à física. Ou então comparam-na a um ovo: a casca à lógica, a parte seguinte (a clara) à ética, e a parte central (a gema) à física. Ou a comparam ainda a um campo fértil: a cerca externa é a lógica, os frutos são a ética, e o solo ou as árvores são a física. Ou comparam-na a uma cidade bem amuralhada e racionalmente administrada. E nenhuma das partes é separada das outras, como dizem alguns estoicos, mas ao contrário todas estão estreitamente unidas entre si. (Idem VII, 40, p. 190-191).

Considerando a interdependência recíproca das partes, nenhuma delas é o melhor ponto por onde começar a aprender a filosofia estoica. Os estoicos propuseram então o ensino da filosofia a partir de vários ordenamentos. A escolha do ponto de partida dependia das atitudes e dos antecedentes culturais do aluno: "Seu próprio ensino fazia-se conjuntamente. Outros estoicos, entretanto, dão o primeiro lugar à lógica, o segundo à física e o terceiro à ética. Entre estes estão Zênon em seu tratado Sobre a Lógica, Crisipos, Arquêdemos e Êudromos." (Ibidem VII, 40, p. 191).

Caso se escolha a ética como ponto de partida, é necessário passar por duas etapas. Antes de tudo se estuda a própria ética. Depois se aprende as outras partes da filosofia estoica, de modo a colocar a ética no contexto geral. No De finibus III 70-74, Cícero elenca as vantagens de se dedicar às outras partes da filosofia estoica: É preciso compreender a lógica para defender-se dos adversários e ter uma firme convicção sobre a própria posição. Existe a necessidade da física para situar a ética no contexto da totalidade do mundo e da compreensão humana acerca dele. De modo particular se deve compreender a relação entre a natureza humana e aquela do mundo, sendo que nesta última o homem não é senão uma minúscula parte, um microcosmo.

Qualquer pessoa pode, sem dúvida, decidir a se restringir ao estudo da ética, ignorando as outras partes da filosofia estoica. Em tal caso haverá uma compreensão mais limitada e menos segura da ética estoica comparativamente a quem resolve aprender toda a filosofia estoica. Ainda assim a escolha por estudar somente a ética estoica proporcionará uma compreensão suficiente para apresentá-la e defendê-la dos adeptos dos sistemas éticos antagônicos. No De finibus, Cícero apresenta as teorias éticas estoica, epicurista e peripatética no contexto de raciocínios pró e contra, sem valer-se da física e da lógica estoica, ou de outro tipo. Na Roma de Cícero, muitas pessoas cultas desejavam estabelecer, por exemplo, se o fim último da vida era a virtude, como sustentavam os estoicos, ou ainda o prazer, como ensinava Epicuro, sem ter que se confrontar com os detalhes da lógica e da metafísica. Um desejo mais que natural, visto que a resposta a tal indagação não deveria depender da solução de complicadas questões lógicas ou metafísicas. Seria possível, portanto, estudar a ética, superficialmente ou com certa profundidade, sem que se fizesse referência às outras partes da filosofia estoica.

8 A formulação da divisão tripartite da filosofia segundo o estoicismo aparece em D.L. VII, 40. 
Três foram os textos antigos que chegaram até nós e que adotam esta estratégia. Um desses textos é a exposição de Cícero no terceiro livro do De finibus, onde as habilidades retóricas do Arpinate são postas a serviço da compreensão das principais teses estoicas. Por esse motivo ela permanece ainda como a mais popular versão da ética estoica. As outras duas fontes são: o livro VII do Vidas e doutrinas dos filósofos ilustres de Diógenes Laércio e o livro ll das Éclogas de Giovanni Estobeu" ${ }^{9}$, atribuído geralmente a Ário Dídimo. Estas duas versões derivam de fontes semelhantes e tratam os temas principais da ética estoica com certa medida de tecnicismo. Nenhuma delas parece ter como destinatário o principiante, e ambas parecem escritas por um autor que consultou manuais técnicos e produziu um destilado das ideias ali contidas, sem se preocupar muito em fornecer uma exposição bem organizada.

A versão de Diógenes, ainda que não possua a qualidade retórica do texto de Cícero, é fonte preciosa, pois contempla o estudo de conceitos estoicos importantes e suas conexões com um grau maior de rigor. Enquanto Cícero deseja persuadir o auditório e se lamenta do estilo difícil e obscuro dos estoicos ${ }^{10}$, Diógenes, sem se preocupar em dar uma feição mais de divulgação às exposições dos estoicos, não dissimula as dificuldades e as frequentes excentricidades da filosofia estoica, que por vezes apresenta raciocínios pouco sedutores e até mesmo tediosos.

Se traçarmos um plano geral da exposição de Diógenes, observaremos que ele inicia sua apresentação com um elenco de temas éticos dispostos em uma ordem diferente daquela de sua efetiva exposição. Ele tem por base a evolução do "primeiro impulso" do ser vivo, que é introduzido na descrição do fim último do homem como "viver segundo a natureza" e "viver segundo a virtude". Diógenes dirige em seguida a sua atenção à virtude e aos bens, uma discussão que ocupa uma ampla parcela do texto. Depois ele se dedica aos indiferentes e aos deveres; mas a esta altura não aborda as ações retas e passa diretamente às paixões. A sua seção final representa uma espécie de mescla de temas, sobretudo de ética aplicada, vagamente centrados sobre a ideia de sábio.

Um importante princípio que organiza o texto é a clara diferença estabelecida entre a virtude, que é boa, e coisas como riqueza, glória, saúde, força e semelhantes ${ }^{11}$, que comumente seriam definidas como "boas", mas que os estoicos chamam de "indiferentes". Diógenes dedica tempo considerável a distinguir os diferentes significados do conceito de "bondade" e a esclarecer a natureza da virtude, fato que não surpreende se considerarmos que a ética estoica apresenta uma necessidade de estabelecer uma clara distinção entre o tipo de valor atribuído à virtude e aquele atribuível a qualquer outro gênero de coisa que comumente é considerada boa, assinalando dessa forma toda a importância que há para os estoicos em destacar a diferença entre os dois tipos de valores. Limitando a aplicação do adjetivo "bom" à virtude e aos usos a ela associados, os estoicos nos fazem compreender que aquela distinção diz respeito a aquilo que denominamos de diferença entre valor moral e valor não moral. Não obstante a importância de tal diferença para a exposição de Diógenes, em seu texto não há nada, exceção feita para a breve passagem anteriormente mencionada, que sirva para justificar tal distinção ou para torná-la mais compreensível.

\footnotetext{
9 Giovanni Estobeu foi um erudito do século V d.C. que recolheu excertos dos mais variados prosadores e poetas gregos em uma ampla antologia, a fim de proporcionar ao filho Setímio, pouco amante do estudo, um meio fácil de educar-se na cultura clássica. Para o estudo dos textos de Estobeu indicamos a obra L'Antologia di Giovanni Stobeo - Una biblioteca antica dai manoscritti alle stampe, de Michele Curnis, publicado em 2008 pela Edizioni dell' Orso.

${ }^{10}$ Conforme encontramos em De finibus bonorum et malorum III, 4.

${ }^{11}$ Cf. D.L. VII, 104.
} 
O ponto de partida da exposição de Diógenes é a tese segundo a qual os seres vivos nascem com o impulso para amar e para se preservar, e portanto para fazer o que promove a autoconservação:

Os estoicos dizem que o primeiro impulso do ser vivo é o da sobrevivência, que lhe foi dado desde o início pela natureza. No primeiro livro de sua obra Dos Fins, Crisipos afirma que o primeiro bem possuído por cada ser vivo é a sua própria constituição física e a consciência de si mesma. Não se pode admitir logicamente que a natureza torne o ser vivo estranho a si mesmo (de outra forma ela não o teria criado), nem que o trate como um estranho, nem que não o tenha como sua criatura. Somos então compelidos a dizer que a natureza, constituindo o ser vivo, fê-lo caro a si mesmo, pois assim ele repele tudo que é prejudicial, e acolhe tudo que lhe é útil e afim. (D.L. VII, 85, p.201).

Encontramos também outro argumento em sustento da concepção estoica do primeiro impulso como autoconservação, apresentado na forma de uma crítica aos adversários epicuristas:

Os estoicos demonstram que falam falsamente todos os propugnadores da ideia de que $o$ primeiro impulso dos seres vivos é em direção ao prazer. De fato, esses filósofos afirmam que o prazer, se realmente existe, vem num segundo estágio, quando a natureza por si mesma procurou e encontrou tudo que se adapta à sua constituição; deste modo, os animais têm a índole jovial e as plantas florescem. Eles dizem ainda que a natureza não faz diferença alguma entre as plantas e os animais, porque regula também a vida das plantas, em seu caso sem impulso e sem sensações, e por outro lado geram-se em nós fenômenos análogos ao das plantas. Mas, já que no caso dos animais foi acrescentado o impulso por meio do qual os mesmos se dirigem a seus próprios fins, daí decorre que sua disposição natural atua no sentido de seguir o impulso.(D.L. VII, 85-86, p. 201).

Tanto os estoicos quanto os epicuristas tomam como exemplo o comportamento dos recém-nascidos para argumentar em favor de suas teorias éticas, com conclusões porém bastante diferentes. Os epicuristas sustentam que a busca do prazer e o evitar da dor, que são instintivos para os recém-nascidos, são a forma que os impulsos humanos possuem quando estão em um estado não corrompido: isto nos permite intuir como seria o homem se os seus impulsos não fossem corrompidos. Os estoicos se opõe a este posicionamento afirmando que os epicuristas erram sobre aquilo que pensam terem explicado. Na verdade, os recém-nascidos não procuram o prazer, dado que este não é qualquer coisa a qual se possa aspirar, mas sim alguma coisa que advém em um segundo momento quando se busca outra coisa, ou seja, a preservação do próprio eu e da própria constituição física, uma procura com a qual, segundo os estoicos, a natureza nos familiarizou. Um epicurista poderia evitar tal argumento apenas colocando em discussão a teoria sobre a natureza do prazer, que lhe serve de base, mas isto conduziria a discussão para um terreno diferente.

Segundo Diógenes, a natureza dota o homem do impulso a se autoconservar instintivamente, e os seres racionais desenvolvem a capacidade de se autoconservar de modo racional, ou seja, de um modo que requer a reflexão muito mais que o mero instinto:

E já que os seres racionais receberam a razão com vistas a uma conduta mais perfeita, sua vida segundo a razão coincide exatamente com a existência segundo a natureza, enquanto a razão se agrega a eles como aperfeiçoadora do impulso. Por isso Zênon foi o primeiro, em sua obra Da Natureza do Homem, a definir o fim supremo como viver de acordo com a natureza, ou seja, viver segundo a excelência, porque a excelência é o fim para qual a natureza nos guia. (D.L. VII, 86-87, p. 201).

O homem deve viver em conformidade com a própria natureza e com a do universo, visto que a natureza humana faz parte da natureza universal. 
No primeiro livro de sua obra Dos Fins, Crisipos afirma também que viver segundo a excelência coincide com viver de acordo com a experiência dos fatos da natureza, e que nossas naturezas individuais são partes da natureza universal. Por isso o fim supremo pode ser definido como viver segundo a natureza ou, em outras palavras, de acordo com nossa própria natureza e com a natureza do universo, uma vida em que nos abstemos de todas as ações proibidas pela lei comum a todos, idêntica à reta razão difundida por todo o universo e idêntica ao próprio Zeus, guia e comandante de tudo o que existe. E nisso consiste a excelência do homem feliz, e consiste o curso suave da vida, quando todas as ações praticadas promovem a harmonia entre o espírito existente em cada um de nós e a vontade do ordenador do universo. (Idem VII, 87-88, p. 201-202).

Tal tipo de vida, ou seja, "viver em conformidade com a natureza", é identificado com a virtude do homem feliz, ainda que não haja no texto de Diógenes um argumento em condições de estabelecer um nexo entre o viver segundo a natureza humana, ou a natureza universal, e a virtude. A passagem da natureza humana àquela universal e a retomada do tema da virtude não parecem claras no estado em que o texto de Diógenes chegou até nós. É possível que neste caso, Diógenes tenha compendiado um argumento mais extenso, ou tenha efetuado uma compilação de fontes diferentes. É muito provável que se trate de uma versão incompleta daquilo que encontramos em estoicos tardios como Epicteto e Marco Aurélio. A tese é de que nós seres humanos somos simplesmente parte de uma totalidade mais ampla. Esta linha de raciocínio não explica claramente porque o que é natural para nós deva identificar-se com a virtude, ou porque esta última deveria nos tornar felizes. Deve-se presumir que a natureza universal seja organizada de maneira tal a tornar os seres humanos felizes quando são virtuosos; todavia no texto de Diógenes esta premissa essencial não é desenvolvida, nem apresentada como parte da ética estoica.

Na verdade, o texto de Diógenes constitui um exemplo de abordagem ética com caráter misto, ou seja, assim como acontece frequentemente nos estoicos do período imperial, as teses éticas são apresentadas misturadas a teses metafísicas, limitando portanto a plena compreensão que derivaria, ao contrário, a partir do aprendizado em separado da metafísica e da ética, para situar depois a segunda no contexto da primeira. A escolha expositiva de Diógenes dá lugar ao menos a três consequências indesejáveis:

1) As ideias metafísicas são expostas, mas não desenvolvidas, o que torna as ideias éticas menos compreensíveis;

2) As ideias éticas irrompem de improviso no texto de Diógenes, o que o faz, daquele momento em diante, concentrar-se somente sobre elas;

3) Além disso, as ideias éticas interrompem o desenvolvimento da concepção de oikeiosis e ocorre uma passagem da natureza humana à natureza universal sem coerência, para em seguida retornar à virtude. Deve-se, porém, considerar aqui a possibilidade de que esta seção do texto de Diógenes seja o resumo de um argumento que na forma mais completa instituía nexos mais claros e compreensíveis.

Os longos parágrafos iniciais de Diógenes dizem respeito aos bens e à virtude e estabelecem numerosas diferenciações entre ambos ${ }^{12}$. Ao longo da discussão são traçadas numerosas distinções entre a virtude e os bens. Ele reconhece o princípio organizativo segundo o qual as coisas são divididas em bens, males e indiferentes, ainda que tal princípio seja reco-

${ }^{12}$ Cf. D.L. VII, 90-101. 
nhecido em uma fase posterior da exposição ${ }^{13}$, porém ele não organiza claramente o seu material com base nisso.

Consideramos que a virtude seja boa, como também o são a saúde, a riqueza e etc. Embora muitas entidades diferentes sejam boas em modos diversos, supomos que a bondade delas seja pelo menos confrontável, de modo que, por exemplo, se a virtude torna uma vida boa, a união da saúde com a virtude irá torná-la ainda melhor. Os estoicos refutaram esta ideia e com ela as considerações teóricas implícitas em distinções da linguagem comum como, por exemplo, a distinção corrente entre os bens da alma, bens do corpo e bens exteriores. Aristóteles menciona tal distinção como parte do senso comum ${ }^{14}$ e a torna o ponto de partida da discussão filosófica. Os estoicos sustentam de modo firme que somente a virtude é boa e oferecem um argumento que é proveniente de um raciocínio contido no passo 278-282 do Eutidemo de Platão. $O$ argumento se apresenta da seguinte maneira: aquilo do qual se pode fazer bom ou mau uso não é um bem; a virtude, porém, emprega todos os bens comuns, a partir do momento em que estes possuem a mesma relação que um material tem com uma habilidade ou perícia; por isso nenhum bem convencional pode ser bom. Portanto, feita a exceção para a virtude, cada coisa, que normalmente se julga boa, não se pode definir como tal, mas se deve reservar a qualificação de "indiferente":

Da mesma forma que a propriedade do quente é aquecer, e não esfriar, a propriedade do bem é beneficiar, e não prejudicar; a riqueza e a saúde causam mais danos que vantagens, e portanto nem a riqueza é um bem, nem a saúde. Além disso os estoicos dizem que não é um bem aquilo cujo uso nos pode fazer bem ou mal; já que tanto a riqueza como a saúde podem ser usadas para fazer bem ou mal, nem a riqueza é um bem, nem a saúde. (D.L.VII, 103, p. 205).

Em seguida, os estoicos retornam às tradicionais taxonomias dos bens e redesenham os seus limites para evitar que entrem em conflito com o fundamental divisor de águas entre a virtude e qualquer outra entidade, Eles reformulam, portanto, a tripartição intuitiva entre os bens da alma, os bens do corpo e os bens exteriores ${ }^{15}$. Na nova versão, alguns bens são bens da alma, outros são bens exteriores e outros não são nem da alma nem exteriores. Todavia, enquanto o senso comum estabelece uma distinção entre os bens da alma como as virtudes e outras qualidades intelectuais, bens do corpo como a saúde, a força e semelhantes, e bens exteriores como o dinheiro, o extrato social e análogos, todos os elementos da tripartição estoica têm alguma relação com a virtude, e por esta razão é possível classificá-los entre os bens.

Todavia, se somente a virtude é boa, enquanto cada outra coisa julgada boa é simplesmente indiferente, como é possível que seja boa alguma coisa diferente da virtude? Aqui parece que os estoicos dão os seus melhores frutos ao estabelecer distinções. Antes de tudo, sustenta-se que o significado básico do termo "bom" é aquele de "útil", uma tese próxima ao senso comum, a partir do momento em que é comum supor, como já haviam reconhecido Platão e Aristóteles, que todos os homens buscam a felicidade procurando para si coisas boas, coisas que são úteis. $O$ útil que se extrai das coisas é o que os torna felizes: o princípio eudamonístico fundamental segundo o qual todo ato é destinado à felicidade.

Ainda que em sentido estrito somente a virtude seja boa, é legítimo atribuir o adjetivo "boa" a pessoas virtuosas, enquanto a virtude constitui uma parte das coisas que definimos no sentido lato como boas. Obtém-se assim a versão modificada de uma distinção familiar ${ }^{16}$ : os

\footnotetext{
${ }^{13}$ Cf. Idem VII, 101.

${ }^{14}$ Cf. Política VII 1.

${ }^{15}$ Cf. D.L. VII, 95-96.

${ }^{16}$ Cf. D.L. VII, 95-96.
} 
bens da alma são as virtudes e as ações virtuosas; os bens exteriores são o ter amigos virtuosos e uma pátria virtuosa, da qual a virtude é uma parte; o ser virtuoso e feliz é um bem não atribuível aos outros dois, uma vez mais porque a virtude é uma parte deste estado.

Diógenes relata que os estoicos formulam uma distinção entre as coisas classificadas como "indiferentes", sendo que algumas delas devem ser escolhidas e outras rejeitadas. O critério para a escolha é o "valor" e sua contribuição para uma vida equilibrada racionalmente:

Das coisas indiferentes os estoicos dizem que algumas merecem ser escolhidas, e outras merecem ser rejeitadas. Dignas de escolhas são aquelas que têm valor; merecedoras de rejeição serão as destituídas de valor. Eles entendem por "valor" uma certa contribuição à vida equilibrada pela razão, requisito de todo bem; mas, entendem também uma certa potência ou utilidade mediata que contribui para a vida segundo a natureza, como a contribuição que a saúde e a riqueza trazem à vida segundo à natureza; os estoicos tiram outro significado do termo "valor" da troca de mercadorias calculada por um perito no assunto - por exemplo: trocar uma carga de trigo por uma carga de cevada mais o mulo. (D.L. VII, 105, p. 205).

A discussão a respeito do "dever"17, considerado ato passível de ser justificado racionalmente, desde que seja conforme à natureza na vida, segue logo após a exposição sobre os "indiferentes", mas Diógenes, a esta altura, deixa de lado a questão das ações retas e passa diretamente às paixões, consideradas pelos estoicos como "um movimento da alma, irracional e contrário à natureza, ou um impulso excessivo." (D.L. VII, 111, p. 206).

A parte final do livro VII de Vidas e doutrinas dos filósofos ilustres contém uma mescla de temas, sobretudo de ética aplicada, tais como a família, as relações pessoais, comerciais e a política, vagamente alicerçados sobre a ideia do sábio. Para os estoicos, a política não é um âmbito que deva ser tratado fora da ética, mas, na verdade, é uma esfera imbuída de relações éticas. Os temas de ética aplicada são abordados após longas análises e distinções de termos éticos, porque são considerados como aplicações da teoria, e não como temas interessantes por si mesmos.

Os estoicos postulam uma teoria ética que põe em primeiro plano a distinção entre valor moral e valor não moral. Diógenes Laércio nos faz compreender a centralidade deste fato para a ética estoica. Por trás de uma terminologia com a qual não estamos familiarizados e de distinções muitas vezes aparentemente pretensiosas, reconhecemos as linhas gerais de uma aproximação à moral que procura reformular o modo com o qual pensamos o mundo, levando-nos a observá-lo à luz de distinções que são mais nítidas e rígidas que aquelas que traçamos comumente, mas que, sustentam os estoicos, nos são impostas a partir da reflexão filosófica sobre a ética. A exposição de Diógenes Laércio, embora seja menos fluente que aquela de Cícero no livro III do De finibus, consente de colher em modo aprofundado as consequências do repensar estoico sobre o nosso mundo ético.

\section{Referências}

ARISTÓTELES. Política. Tradução, introdução e notas de Mário da Gama Kury. Brasília: Editora da UNB, 1997.

ARNIM, Hans von. Stoici Antichi - Tutti i frammenti. Milano: Bompiani, 2002.

BRENNAN, Ted. A vida estoica - Emoções, obrigações e destino. São Paulo: Edições Loyola, 2010.

${ }^{17}$ A discussão sobre o "dever" se encontra a partir do fim do parágrafo 107 até o início do 110. 
BRUN, Jean. O Estoicismo. Tradução de João Amado. Lisboa: Edições 70, 1986.

CÍCERO, M. T. Textos Filosóficos. Tradução, introdução e notas de J. A. Segurado e Campos. Lisboa: Fundação Calouste Gulbenkian, 2012.

GOURINAT, J. B.; BARNES, J. (Orgs.). Ler os estoicos. Tradução de Paula S. R. C. Silva. São Paulo: Edições Loyola, 2013.

INWOOD, Brad (Org.). Os Estoicos. Tradução de Raul Fiker. São Paulo: Odysseus Editora, 2006.

LAÊRTIOS, Diôgenes. Vidas e doutrinas dos filósofos ilustres. Tradução, introdução e notas de Mário da Gama Kury. Brasília: Editora da UNB, 1977.

PLATÃO. Eutidemo. Tradução de Carlos Alberto Nunes. Belém: EDUFPA, 2007.

RADICE, Roberto. Estoicismo. Tradução de Alessandra Siedschlag. São Paulo: Ideias \& Letras, 2016.

\section{Sobre o autor}

\section{José Carlos Silva de Almeida}

Bacharel e Licenciado em Filosofia pela Pontifícia Universidade Católica do Rio de Janeiro (1989), Mestre em Filosofia pela Pontifícia Universidade Católica do Rio de Janeiro (1992) e Doutor em Filosofia pela Pontifícia Universidade Antonianum - Roma (2005). Professor Associado III do Curso de Filosofia da Universidade Federal do Ceará, atuando principalmente nas seguintes áreas: História da Filosofia Antiga (período helenístico-romano), Ética e Ensino de Filosofia. Membro do PROCAD/CAPES em Filosofia Antiga (UFMG/UFU/UFC). Pós-Doutor em Filosofia Antiga pela UFMG (2019).

Recebido em: 13/05/2020

Aprovado em: 23/07/2020 